\title{
TEKNIK BONE TISSUE ENGINEERING (BTE) UNTUK REGENERASI JARINGAN PERIODONTAL DAN ESTETIK PADA EDENTULOUS RIDGE
}

\author{
Hendri Poernomo, \\ Bagian Bedah Mulut, Fakultas Kedokteran Gigi, Universitas Mahasaraswati Denpasar \\ E-mail : hendri_poernomo@yahoo.co.id
}

\begin{abstract}
The resorption of alveolar bone in the edentulous area can lead to reduced prosthetic support and loss of periodontal tissue attachment, and reduce aesthetics. Dental implants are an alternative treatment option for patients with partial or complete loss of teeth. Not all dental implants provide good results, especially in relation to bone contact with implants. One way to overcome alveolar bone deficiency is implant placement with bone grafting procedures. Bone Tissue Engineering (BTE) can be performed in the edentulous area that experiences alveolar bone resorption, to replace lost bone (osteoconduction) and stimulate new bone formation (osteoinduction), so that the denture in the edentulous area is better with adequate support, and more aesthetics. Osteon (Biphasic Calcium Phosphate) is one of the unique products made from marine coral, which contains Calcium Carbonate in the structure of Calcium Hydroxyapatite. The advantage of this material is that the structure of the sea coral is similar to trabecular bone. Biphasic Calcium Phosphate has several disadvantages, namely slow degradation rates, weak resistance to fractures, high crystallinity, and has limitations in stimulating the regeneration of bone cells; and coated with collagen, so that it can enable immunological / allergic reactions in patients who have hypersensitivity.
\end{abstract}

Keywords: Bone Graft, Bone Tissue Engineering Technique (BTE), Edentulous Area.

\section{PENDAHULUAN}

Kemajuan bidang kedokteran meliputi kedokteran molekuler, biologi molekuler, rekayasa jaringan dan genetik telah membuka pengetahuan baru dalam penanganan berbagai macam kondisi muskuloskeletal. ${ }^{1}$ Penyembuhan kerusakan tulang dengan transplantasi tulang menggunakan metode tissue engineering (rekayasa jaringan) merupakan alternatif dari perawatan konvensional. ${ }^{2}$ Prinsip umum dari tissue engineering adalah mengkombinasikan sel, scaffold atau perancah, dan faktor pertumbuhan. ${ }^{3.4}$ Selsel akan berkembang biak, bermigrasi dan berdiferensiasi menjadi jaringan khusus dan dengan bantuan faktor pertumbuhan sel akan meghasilkan komponen matriks ekstraseluler yang diperlukan untuk pembentukan jaringan. ${ }^{5}$

Scaffold adalah kerangka yang mendukung sel untuk dapat tumbuh dan berkembang menjadi jaringan tulang baru pada daerah kerusakan dengan bentuk dan ukuran seperti yang diharapkan. ${ }^{6}$ Scaffold merupakan komponen yang sangat penting dalam metode tissue engineering. ${ }^{5}$ Scaffold yang ideal adalah yang memiliki kemampuan biocompatible, biodegradable, serta memiliki desain bangun yang mendukung sel untuk tinggal dan berkembang. ${ }^{7}$ Koral laut merupakan biomaterial yang lebih dari satu dekade ini digunakan dalam pembuatan scaffold karena mengandung unsur kalsium karbonat (CaCO3) yang mirip dengan penyusun tulang. Koral laut memiliki sifat biokompatibel, osteokonduktif yang baik, dapat terabsorbsi, menghantarkan faktor pertumbuhan dengan baik, serta mudah diolah sesuai ukuran dan bentuk yang dibutuhkan. ${ }^{8}$ Kelebihan-kelebihan tersebut membuat koral laut sesuai untuk digunakan sebagai perancah dalam rekayasa jaringan tulang. ${ }^{8}$

\section{LANDASAN TEORI}

Rekayasa jaringan adalah teknologi biomedis yang dikembangkan untuk membantu regenerasi jaringan tubuh dalam mengobati cacat dengan ukuran besar yang tidak mungkin diperbaiki sendiri oleh jaringan. ${ }^{9}$

Tissue Engineering atau rekayasa jaringan merupakan pengetahuan multi disiplin yang berlandaskan kedokteran klinis, ilmu material, genetika dan ilmu yang berkaitan dengan ilmu kehidupan dan rekayasa. ${ }^{7}$ Rekayasa jaringan tulang atau Bone Tissue Engineering (BTE) didasarkan pada pemahaman tentang struktur tulang, mekanik tulang, dan pembentukan jaringan yang bertujuan untuk medukung terbentuknya jaringan fungsional tulang baru. ${ }^{10}$

Prinsip dasar rekayasa jaringan tulang bertujuan untuk mengatasi keterbatasan pengobatan konvensional didasarkan pada transplantasi organ dan implantasi biomaterial. Rekayasa jaringan memiliki potensi untuk menghasilkan sebuah suplai organ imunologis toleran buatan yang dapat tumbuh menyatu dengan pasien. Rekayasa jaringan dapat menjadi solusi dari kerusakan organ atau jaringan tanpa perlu terapi tambahan, sehingga biaya pengobatan menjadi lebih efektif. ${ }^{5}$

Bone graft atau cangkok tulang disebut sebagai gold standart terapi tulang. Cangkok tulang digunakan untuk memberikan dukungan, mengisi celah kosong antara tulang dan implan, serta dapat mempercepat penyembuhan pada kelainan skeletal. ${ }^{11}$ Pengganti tulang ini berfungsi pasif membimbing atau mengantar sel bermigrasi melalui matriks, akhirnya mengarah pada perbaikan kerusakan. ${ }^{6}$ Bone graft sebagai materi yang ditanamkan sendiri atau dalam kombinasi dengan bahan lain untuk meningkatkan respon penyembuhan tulang dengan menyediakan unsur osteogenik, osteinduktif dan osteokonduktif. ${ }^{12}$ 
Bahan osteogenik dapat didefinisikan sebagai bahan yang memiliki kapasitas melekat untuk membentuk tulang, yang berarti mengandung sel-sel hidup yang mampu diferensiasi menjadi sel-sel tulang. Bahan osteoinduktif memberikan sinyal biologis menginduksi sel-sel lokal memasuki jalur diferensiasi yang mengarah ke osteoblas dewasa. Biomaterial osteokonduktif menyediakan scaffold tiga dimensi di mana jaringan tulang lokal dapat menumbuhkan tulang hidup baru. Biomaterial osteokonduktif mempunyai kekurangan tidak dapat membentuk tulang atau mempengaruhi pembentukannya. ${ }^{13}$

Scaffold pada rekayasa jaringan adalah perancah berpori 3D yang berfungsi untuk menyediakan lingkungan yang sesuai untuk regenerasi jaringan dan organ. Scaffold pada dasarnya bertindak sebagai template untuk pembentukan jaringan dan biasanya ditambahkan sel punca dan faktor pertumbuhan. ${ }^{7}$

Pemilihan scaffold sangat penting untuk memungkinkan sel dapat bekerja menghasilkan bentuk dan ukuran jaringan maupun organ yang diinginkan. ${ }^{5}$ Syarat yang harus dipenuhi dalam pembuatan scaffold pada rekayasa jaringan harus memiliki pori-pori berukuran tepat yang saling terhubung untuk mendukung integrasi dan vaskularisasi jaringan; terbuat dari material yang dapat mengontrol biodegrabilitas sehingga memungkinkan jaringan baru mengantikan scaffold; mempunyai permukaan yang cocok untuk perlekatan, proliferasi, migrasi, dan diferensiasi sel; memiliki kekuatan mekanis yang cukup; tidak mengandung respon yang merugikan; mudah dibuat menjadi berbagai bentuk dan ukuran. ${ }^{5}$

Biomaterial dari polimer sintetik, polimer alam dan keramik merupakan bahan dasar pembuatan scaffold ${ }^{7}$, yang dapat memberi dukungan mekanis, adhesi, dan proliferasi untuk perlekatan sel pada scaffold. $^{14}$ Bahan polimer sintetik seperti, asam poliglikolik (PGA), asam polilaktat (PLLA), asam poliglikolat-laktat (PLGA) dan polikaprolakton (PCL) merupakan polimer sintetik yang sering digunakan dalam aplikasi perancah pada rekayasa jaringan. ${ }^{5}$

Kelebihan polimer sintetik dapat dibuat bentuk yang beragan dan mudah diproses., mempunyai sifat biokompatibel, biodegradabel, dan dapat terkikis. ${ }^{15}$ Kekurangan polimer sintetik adalah adanya risiko penolakan oleh jaringan karena kuranganya bioaktivitas dalam proses degradasi yang menyebabkan penurunan hidrolisis dan menghasilkan karbon dioksida, sehingga terjadi penurunan $\mathrm{pH}$ lokal yang menyebabkan kematian sel dan jaringan. ${ }^{7}$

Polimer alam mempunyai aktivitas alami yang berguna dalam perlekatan sel karena terdapat komponen matriks ekstrasel dan dapat terabsorbsi secara alami selama pembentukan matriks ekstrasel baru, sehingga scaffold dengan bahan dasar ini memiliki kemampuan biogradabel yang baik. ${ }^{14}$ Polimer alam yang digunakan sebagai bahan rekayasa jaringan yaitu fibrin, kolagen, gelatin, chitosan, alginat dan asam hyaluronic. $^{15}$

Scaffold dengan bahan dasar keramik memiliki sifat mekanik yang kuat tetapi biokompatibel dan biodegradabel yang kurang baik. ${ }^{15}$ Scaffold dari keramik memiliki karakteristik kekakuan yang tinggi, elastisitas yang rendah dengan permukaan yang keras namun rapuh. Penggunaan keramik dalam teknik rekayasa jaringan sangat terbatas karena permukaannya mudah rapuh. ${ }^{\text {T }}$

\section{PEMBAHASAN}

Penyembuhan kerusakan tulang dengan transplantasi tulang menggunakan metode tissue engineering (rekayasa jaringan) merupakan alternatif dari perawatan konvensional. Prinsip umum dari tissue engineering adalah mengkombinasikan sel, scaffold atau perancah, dan faktor pertumbuhan. Cangkok tulang digunakan untuk memberikan dukungan, mengisi celah kosong antara tulang dan implan, serta dapat mempercepat penyembuhan pada kelainan skeletal.

Scaffold merupakan kerangka yang mendukung perlekatan dan proliferasi sel pada daerah kerusakan, menstabilisasi pembekuan darah untuk mencegah gagalnya pembetukan jaringan, dan sebagai inti diawalinya proses regenerasi. ${ }^{6}$ Scaffold berperan juga sebagai pembawa faktor pertumbuhan osteokonduktif. ${ }^{16}$ Sel-sel berkembang biak, bermigrasi dan berdiferensiasi menjadi jaringan khusus dan dengan bantuan faktor pertumbuhan sel akan meghasilkan komponen matriks ekstraseluler yang diperlukan dalam pembentukan jaringan. ${ }^{5}$

Regenerasi tulang dapat terjadi dengan lengkap melalui tiga mekanisme yang berbeda: osteogenesis, osteoinduksi, dan osteokonduksi. Osteogenesis merupakan pembentukan dan perkembangan tulang, bahkan tanpa sel-sel mesenkimal yang tidak berdiferensiasi. $^{17}$ Osteoinduksi adalah transformasi stem sel mesenkimal yang tidak berdiferensiasi ke dalam osteoblast atau kondroblast melalui faktor-faktor pertumbuhan yang ada hanya pada tulang hidup. ${ }^{17}$ Osteokonduksi merupakan proses yang menyediakan fondasi atau rangka sementara/ scaffold biologi, atau matrix fisik, yang sesuai dengan komposisi bentuk tulang baru disekitar tulang mendukung diferensiasi sel-sel mesenkim untuk tumbuh di sepanjang permukaan bahan cangkok tulang. ${ }^{17}$

Jenis awal bahan cangkok tulang adalah autogenus, allograft, xenograft, dan alloplastic. Semua bahan cangkok tulang mempunyai salah satu atau lebih dari ketiga mekanisme tersebut. ${ }^{17}$ Mekanisme tersebut yang merupakan reaksi dari bahan cangkok tulang normalnya dapat ditentukan berdasarkan asal dan komposisinya. Autogenous didapat dari pasien itu sendiri dan mempunyai kemampuan membentuk tulang baru dalam aksi osteogenesis, osteinduksi, dan osteokonduksi. ${ }^{17}$ Allograft didapatkan dari cadaver dalam spesies yang sama, mempunyai sifat osteokonduksi dan kemungkinan osteoinduksi, tetapi tidak osteogenesis. ${ }^{17}$ Xenograft dan Alloplastik graft hanya mempunyai sifat utama sebagai osteokonduksi. Alloplastik merupakan bahan cangkok tulang buatan yang inert. Bahan cangkok tulang yang paling utama digunakan adalah calcium carbonate, calcium sulfate, polimer bioaktif glass, dan bahan keramik, termasuk HA buatan dan tricalcium phosphate (TCP). ${ }^{17}$ 
Mekanisme aksi dari bahan-bahan tersebut yang pasti adalah osteokonduksi. Bahan-bahan tersebut menyediakan fondasi/rangka sementara untuk meningkatkan perbaikan dan pertumbuhan jaringan tulang. ${ }^{17}$ Pemilihan penggunaan bahan-bahan cangkok tulang (satu jenis atau kombinasi), tergantung dari kapasitas pemulihan sistemik individu, yaitu potensi penulangan baru pada area defek, dan waktu yang tersedia untuk pematangan bahan cangkok tulang. ${ }^{17}$ Area defek yang besar dan kemampuan penulangan baru rendah lebih baik menggunakan autograft, sedangkan yang kecil dapat menggunakan jenis xenograft atau alloplastic graft. Bila diperlukan untuk hasil yang lebih optimal sesuai dengan kasus yang dihadapi, dapat ditambahkan aplikasi membrane sebagai barrier. ${ }^{17}$

\section{Carbonate-Hydroxyapatite (CHA)}

Komponen anorganik penyusun tulang, email, dan dentin kurang tepat bila dikatakan berstruktur kimia hydroxyapatite, lebih tepatnya bila dikatakan membentuk struktur ion karbonat apatit. ${ }^{17}$ Ion karbonat apatit telah dicoba disintesis dengan beberapa metode dan terbukti mempunyai karakteristik morfologi dan kekuatan mekanis yang cocok sebagai material pengganti tulang. ${ }^{17} \quad$ Berdasarkan hasil penelitian lain, terbukti bahwa karbonat apatit sintetis dapat mempercepat proses penulangan baru dan unsur tersebut dapat mengatur penyeimbangan kinerja tiap sel-sel tulang dan memiliki kemampuan biodegradasi yang baik. ${ }^{18}$ Karbonat apatit dapat disintesis melalui berbagai macam metode, misalnya melalui proses hidrotermal gypsum; ataupun melalui proses fosfatisasi kalsium karbonat. ${ }^{18}$

Karbonat apatit juga dapat diperoleh melalui sintesis kimiawi antara $\mathrm{Ca}(\mathrm{OH}) 2$ dan $\mathrm{H} 3 \mathrm{PO} 4$ melalui proses maturasi 2 jam ataupun 17 jam yang dapat menghasilkan $\mathrm{CHA}$ dengan kristalinitas rendah. ${ }^{18}$ Hal ini seperti yang telah diketahui dari penelitianpenelitian yang ada bahwa bentukan mineral jaringan keras manusia mengandung hydroxyapatite, berisi sejenis ion murni seperti, carbonate, sodium, magnesium, dan lain-lain. ${ }^{18}$

CHA sintesis menggambarkan aktivitas biologis lebih baik daripada HA, karena dengan memasukkan unsur carbonate ke dalam hydroxyapatite menyebabkan peningkatan solubilitas, menurunkan kristalinitas perubahan dalam morfologi kristalnya, dan mempertinggi reaktivitas kimia dengan pengikatan sementara jaringan tulang. ${ }^{18} \mathrm{CHA}$ sebenarnya lebih meningkatkan konsentrasi lokal ion $\mathrm{Ca}$ dan Phosphate yang penting dalam pembentukan tulang baru. Komposisi dari CHA, dibentuk dari bahan Gypsum dan Ca-Hydroxyde yang banyak diperoleh di Indonesia dan dilapisi gelatin yang tidak menimbulkan reaksi imunologi/ alergi. ${ }^{18}$

\section{Biphasic Calcium Phosphate (B-TCP)}

Sebagai bahan untuk regenerasi tulang, bioceramic biasanya mempunyai fungi osteokonduksi yang baik dan aktivitas biologis dengan bentukan mineral yang mirip jaringan tulang asli. ${ }^{19}$ Salah satu bahan cangkok tulang yang termasuk bioceramic golongan hidroksiapatit adalah beta-tricalcium phosphate yang merupakan bahan yang dapat mewakili komponen tulang dan dapat menstimulasi regenerasi jaringan tulang. ${ }^{19}$

Bahan cangkok tulang seperti hydroxyapatite buatan dan Beta-Tricalcium Phosphate cukup menjanjikan, karena berasal dari alam dan memiliki kemampuan untuk memfasilitasi pembentukan tulang baru. ${ }^{20}$ Komposit Biphasic Calcium Phosphate (70\% HA dan $30 \% \quad \beta$-TCP), bersifat biokompatibel, dapat meningkatkan pembentukan tulang baru, dan melalui efek osteokonduksi dapat menambah masa tulang di area defek. ${ }^{20}$

Osteon (Biphasic Calcium Phosphate) merupakan salah satu produk unik yang berbahan dasar koral laut, mengandung unsur Calcium Carbonate di dalam struktur Calcium Hydroxyapatite. ${ }^{20}$ Keuntungan bahan ini adalah struktur koral laut tersebut mirip dengan trabekula tulang, ${ }^{20}$ tetapi mempunyai beberapa kelemahan, yaitu laju degradasinya lamban, ketahanan terhadap fraktur lemah, kristalinitasnya tinggi, dan mempunyai keterbatasan dalam menstimulasi regenerasi sel-sel tulang serta dilapisi dengan kolagen, sehingga dapat memungkinkan terjadinya reaksi alergi pada pasien yang memiliki hipersensitivitas. ${ }^{20}$

\section{KESIMPULAN}

Karbonat apatit yang merupakan material yang memiliki kemampuan biodegradasi yang baik sehingga dapat mempercepat proses penulangan baru dan dapat mengatur keimbangan kinerja tiap sel-sel tulang. Osteon (Biphasic Calcium Phosphate) memiliki struktur koral laut yang mirip dengan trabekula tulang tetapi mempunyai beberapa kelemahan, yaitu laju degradasinya lamban, ketahanan terhadap fraktur lemah, kristalinitasnya tinggi, dan mempunyai keterbatasan dalam menstimulasi regenerasi sel-sel tulang; serta dilapisi dengan kolagen, sehingga dapat memungkinkan terjadinya reaksi imunologi/alergi pada pasien yang memiliki hipersensitivitas.

\section{UCAPAN TERIMA KASIH}

Penulis mengucapkan terima kasih kepada Tuhan Yang Maha Esa, keluarga penulis dan semua pihak yang telah membantu dalam penyelesaian artikel ini.

\section{DAFTAR PUSTAKA}

1. Peng L, Jia Z, Yin X, Zhang X, Liu Y, Chen $\mathrm{P}$, Ma K, Zhou C. Comparative analysis of mesenchymal stem cells from bone marrow, cartilage, and adipose tissue. Stem Cells Dev, 2008,Vol.4:p.761-73.

2. Winoto, A. Comparative analysis of mesenchymal stem cell from bone marrow and adipose tissue for osteogenic differentiation, 2010, p.38.

3. Zhang, N., wu, Y. P., Qian, S. J., Teng, C., Chen, S., \& Li, H. Review article: Research progresss in the mechanism of effect of PRP in bone deficiency healing, 2013. 
4. Sachlos E, Czernuszka JT, Making tissue engineering scaffolds work. Review: the application of solid freeform fabrication technology to the production of tissue engineering scaffolds. Eur Cell Mater, 2003 Jun 30; Vol 5:p.29-39;

5. Kaigler D, Avila G, Wisner-Lynch L, Nevins ML, Nevins M, Rasperini G, Lynch SE, Giannobile WV,. Platelet-derived growth factor applications in periodontal and peri-implant bone regeneration. Expert Opin Biol Ther, 2011 Vol. 3:p 375-85.

6. Hou, R., Chen, F., Yang, Y., Cheng, X., Gao, Z., Yang, H. O., et al. Comparative study between coral-mesenchymal stem cells-rhBMP-2 composite and auto-bone-graft in rabbit criticalsized cranial defect model. Journal of Biomedical Materials Research, Part A, 2006. p 85-93.

7. Tabata, Y. Tissue Regeneration Based on Drug Delivery Technology , Institute for Frontier Medical Sciences, Kyoto University, 53 Kawaracho Shogoin, Sakyo-ku, Kyoto 606-8507, 2003, Japan.

8. Amini, A. R., Laurencin, C. T., \& Nukavarapu, S. $\mathrm{P}$. Bone tissue engineering: recent advances and challenges.Biomed Eng, 2012; 40(5): p.363-408.

9. Bauer, T. W., \& Muschler, G. F. Bone graft materials: An overview of the basic science. Clin Orthop Relat Res, 2000 (371):p.10-27.

10. Torres, J., Tamimi, F., Alkhraisat, M., Frutos, J. P., \& Cabarcos, E. L. Bone subtitutes. J. Implant Dentistry, 2011.

11. Enrione, J., Osorio, F., Lopez, D., Oppenheimer, C.W., \& Fuentes, M.A. Characterization of a Gelatin/Chitosan/Hyaluronan scaffold-polymer. Electronic Journal of Biotechnology, 2010. Vol. 13. No. 5.

12. Gaikwad, V. V., Patil, A. B., \& Gaikwad, M. V. Scaffold for Drug Delivery in Tissue Engineering.
International Journal of Pharmaceutical Science and Nanotechnology, 2008. Vol 1, p.113-122.

13. Hout, W. M., van der Molen, A. M., Breugem, C. C., Koole, R., \& Van Cann, E. M. Reconstruction of the alveolar cleft: can growth factor-aided tissue engineering replace autologous bone grafting? A literature review and systematic review of results obtained with bone morphogenetic protein-2. ,Clin Oral Invest 5(3), 2011. p.297-303.

14. Liu, J. Dan Kerns, D. G., Mechanisms of Guided Bone Regeneration, The Open Dentistry Journal, 2014, 8 (Suppl 1-M3) 56-65,

15. Ana, I. D., Matsuya, S., and Ishikawa, K., Engineering of Carbonate Apatite Bone Substitute Based on Composition-Transformation of Gypsum and Calcium Hydroxide, Int. J. Communication, Network, and System Sciences, 2010, 10:4236

16. Kim, David, M., Camelo, M., Nevins, M., Schupbach, P., Nevins, M., Alveolar Ridge Reconstraction with A Composite Alloplastic Biomaterial, The International Journal of Periodontics and Restorative Dentistry, Harvard School of Dental Medicine, 2012, Boston.

17. Kumar, P., Vinitha, B., Fathima, G., Bone Graft in Dentistry, J. Pharm Bioallied Sci. Juni 2013, 5: S125-S127.

18. Bouler, J.M., LeGeros R.Z., Daculsi G., , Biphasic Calcium Phosphates: Influence of Three Synthesis Parameters on The Ha/b-TCP Ratio, $J$. Biomed Mater Res, 2000,51:680-684.

19. O'Brien, F. J. Biomaterials and scaffold for tissue engineering. Anatony articles, 2011.

20. Tanimoto, Y., Nishiyama N., Preparation and Physical Propeerties of Tricalcium Phosphate Laminates for Bone-Tissue Engineering, $J$. Biomed Mater Res , 2008, A85: 427-433. 